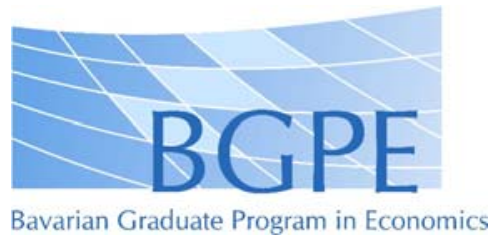

BGPE Discussion Paper

No. 121

\title{
The Effect of Education on Fertility: Evidence from a Compulsory Schooling Reform
}

\section{Kamila Cygan-Rehm Miriam Maeder}

July 2012 


\title{
The Effect of Education on Fertility: Evidence from a Compulsory Schooling Reform
}

\author{
Kamila Cygan-Rehm (University Erlangen-Nuremberg) \\ and \\ Miriam Maeder (University Erlangen-Nuremberg)*
}

July 2012

\begin{abstract}
This study analyzes the effect of education on the number of children, childlessness, and the timing of births. We use exogenous variation from a mandatory reform of compulsory schooling in West Germany to deal with the endogeneity of schooling. In contrast to studies for other developed countries, we find a significant negative effect of education on fertility. This negative effect seems to operate mainly through a postponement of first births away from the teenage years. In addition, education reduces the probability of first motherhood among women in their early 30 s. We attribute these findings to the particularly high opportunity costs of child-rearing in Germany.
\end{abstract}

Key Words: fertility, education, timing of births, childlessness, educational reform

JEL classification: I21, J13, J24

Correspondence to:

Kamila Cygan-Rehm

Economics Department

University of Erlangen-Nuremberg

Lange Gasse 20

90403 Nuremberg

Germany

Phone: +49 - 911 - 5302261

Email: kamila.cygan-rehm@wiso.uni-erlangen.de

\footnotetext{
* We thank Regina T. Riphahn, Joshua Angrist, Anders Björklund, Martina Eschelbach, Boris Hirsch, Daniel Kühnle, Michael Zibrowius, participants of the ESPE 2012 in Bern and the SOEP conference 2012 in Berlin for useful comments on earlier versions of this paper. The usual disclaimer applies.
} 


\section{Introduction}

Population aging challenges social security systems including health care systems and public pensions. The continuous decline in birth rates and the increasing share of childless women in the developed world accelerate recent demographic changes. Since the 1970s total fertility rates (TFR) have fallen substantially in various developed countries. Germany exhibits one of the fastest fertility declines worldwide. Remarkably, Germany's fertility rate already fell below the replacement level of 2.1 children in 1970 and has since decreased to 1.4 in 2009 (Federal Bureau of Statistics 2007). In 2009, German women reached first motherhood on average at age 30. This age at first birth is one of the highest among OECD countries (OECD 2011). Furthermore, the observed increase in the share of childless women additionally contributes to the drop in birth rates (OECD 2011).

The causes of these negative fertility trends are still not fully understood. Various factors such as female employment rates and educational attainment are correlated with total fertility (D'Addio \& D'Ercole 2005). However, recent studies for developed countries do not support the hypothesis that increased education causally reduces fertility, because the negative educationfertility-relationship disappears or becomes even positive after controlling for the endogeneity of schooling (see, e.g., Monstad et al. 2008, Fort et al. 2011, McCrary \& Royer 2011). Nonetheless, the existing evidence on the education-fertility-nexus for European countries is mixed. Different results across countries may reflect the importance of different channels through which education affects fertility (e.g., opportunity costs or assortative mating).

This study examines the causal effect of education on three fertility outcomes: the number of children, the probability of remaining childless, and the timing of births. We use two large datasets: the German Mikrozensus, and the German Socio-Economic Panel to analyze the fertility of West German women born between 1937 and 1961.

We exploit a reform that extended mandatory schooling from 8 to 9 years in West Germany. We take advantage of this exogenous variation in schooling to deal with potential omitted variable bias. In particular, our identification strategy exploits exogenous variation in education resulting from the staggered implementation of the reform in the West German states. By applying an instrumental variables approach we identify the causal effect of education on fertility. 
We find that one additional year of schooling reduces the number of children by more than 0.1 , and increases the probability of childlessness by about 2-5 percentage points. Our analysis of the timing of births suggests that education causally reduces the probability of teenage births. Such birth postponement away from teenage motherhood is consistent with earlier research (see, e.g., Black et al. 2008, Monstad et al. 2008) and may reflect the incompatibility of schooling and motherhood. In addition, we find that education decreases the probability of giving the first birth between the ages of 31 and 35. This effect may work either through higher opportunity costs or be a consequence of age-related changes in fecundity. Our findings for Germany are important, because there is no previous causal evidence for developed countries suggesting that education restricts motherhood, and permanently reduces family size. ${ }^{1}$ We argue that, in contrast to other countries, the strong negative effect of education on completed fertility is mainly driven by the substantial opportunity costs of child-rearing in Germany. Specifically, we focus on West Germany and thus study an institutional setting marked by high wage penalties for motherhood and very limited supply of public childcare (Charles \& Luoh 2003, Kreyenfeld 2004). Our results are robust to a number of robustness checks (specification tests, sample restrictions).

This paper is structured as follows: section 2 briefly describes the German school system and the reform of compulsory schooling. Section 3 presents the theoretical considerations, summarizes existing evidence, and derives our hypotheses. In section 4 we introduce our empirical approach. Section 5 describes the data, section 6 presents the results, and section 7 shows robustness checks. We conclude in section 8 .

\section{Institutional setting}

The German secondary school system is a tripartite system which sorts students into school tracks at the age of $10 .^{2}$ The three school tracks, i.e. basic school (Hauptschule), middle school (Realschule), and high school (Gymnasium), prepare for different careers. Basic school lasts until grades 8 or 9 and prepares for apprenticeship trainings. Middle school includes 10 grades

\footnotetext{
1 The existing causal studies for the U.S. and several European countries usually suggests that extended education leads to postponement of first birth away from teenage motherhood, but does not affect completed fertility (see, e.g., Black et al. 2008, Monstad et al. 2008, Silles 2011).

2 In recent years, some of the German states changed the school system to a two-track system. These changes do not affect the birth cohorts under study.
} 
and prepares for apprenticeships and training in white collar jobs. Graduation from high school after 12 years (Fachhochschulreife) gives access to technical colleges (Fachhochschule). The school leaving certificate traditionally gained after 13 years (Abitur) qualifies for university study.

Figure 1 gives the share of students graduating from the three tracks for the birth cohorts 1932-1965. We observe decreasing shares of basic school graduates and increasing shares of high school and middle school graduates for the younger cohorts. The share of basic school graduates for pre-1935 cohorts was over 80 percent and fell to below 40 percent for the cohorts born after 1960. Accordingly, in the observed period the share of high school graduates increased from about 8 percent to about 23 percent. Thus, educational expansion in Germany led to a sizeable shift of graduates away from basic schools.

\section{[Figure 1 about here]}

The sorting of students into the different tracks depends on various criteria and differs by state. ${ }^{3}$ Assignment to a particular track strongly affects subsequent careers because students rarely change tracks (Pischke 2007, Dustmann 2004). Switching to lower tracks is more frequent than switching to higher tracks (Jürges \& Schneider 2007).

The reform that we use for our identification strategy extended compulsory schooling by one year (from 8 to 9 years) between 1946 and 1969. ${ }^{4}$ The motives for the reform were twofold: first, 14 year old pupils were considered to be too immature for the labor market. Thus, an extension of compulsory schooling aimed at improving vocational maturity, the physical and psychological development of children, and the quality of occupational choices (Petzold 1981). The second argument was related to the high level of youth unemployment and a shortfall of apprenticeship training positions in the 1950s. The schooling reform thus aimed at directing young workers away from manual to more intellectually demanding jobs (Petzold 1981).

[Table 1 about here]

\footnotetext{
3 In some states parents decide about the track their child attends after primary school. In others only primary school grades determine the eligible tracks. In most states sorting follows the recommendation of primary school teachers and the choice of parents (see KMK (2010a) for a description of transition processes to secondary school tracks, and KMK (2010b) for a detailed description of the school system).

4 A number of studies has already exploited the German reform of the extension of compulsory schooling. See, e.g., Pischke \& von Wachter (2008), Brunello et al. (2009), Siedler (2010), Kemptner et al. (2011), Piopiunik (2011), Fort et al. (2011).
} 
The German school system is governed at the level of the federal states. This decentralized organization lead to a staggered implementation of the 9th grade by state. Table 1 shows the year of implementation and the first affected birth cohort by state. While some states such as Hamburg and Schleswig-Holstein introduced the 9th grade shortly after the World War II, others such as Bavaria postponed the reform until the 1960s. ${ }^{5}$ Some states implemented the reform simultaneously with the standardization of the starting date of the school year, i.e. states where school traditionally started in spring shifted the start to the fall. ${ }^{6}$

\section{Literature and hypotheses}

From a theoretical perspective, the predicted effect of an exogenous increase in a woman's education on her fertility is ambiguous because it depends on different substitution and income effects. Economists emphasize several causal channels by which education could affect fertility choices.

The standard microeconomic model of fertility stresses the role of the labor market channel (Becker et al. 1960). On the one hand, education increases women's permanent wages and thus raises the opportunity costs of leaving the labor market to rear children (Becker 1965, Willis 1973). This substitution effect tilts women's optimal fertility choices towards fewer children. On the other hand, economic theory suggests that an increase in labor earnings should be positively related to fertility if families can afford more children (Becker et al. 1960). However, the strength of this income effect may be weakened if parents with higher income prefer children of higher quality (Becker \& Lewis 1973). The more parents invest in each child, the fewer they can afford.

The mating market represents another channel by which education could affect fertility. Under positive assortative mating, a woman's education is causally related to her partner's education (Behrman \& Rosenzweig 2002). Consequently, an exogenous increase in a woman's education affects her permanent income through a spouse-related multiplier effect. Another causal mechanism emphasized by the literature works through the effect of education on women's

\footnotetext{
5 The timing of the reform at the local level varied also within the states because of shortfalls of teachers and a lack of infrastructure in rural areas (Leschinsky \& Roeder 1980).

${ }^{6}$ See Pischke (2007) for a detailed description of the long and short school years.
} 
knowledge about contraception or reproductive health (Grossman 1972, Rosenzweig \& Schultz 1989).

Finally, education may affect childbearing through what as been termed a pure "incarceration effect" because enrollment in the educational system itself may be incompatible with motherhood (see, e.g., Black et al. 2008). However, such birth postponement may be temporary and does not necessarily affect completed fertility (see, e.g., Lappegård \& Rønsen 2005).

Although an extensive empirical literature documents the association of female education and childbearing, a causal relationship is difficult to establish because of potential reverse causality and selection on unobservable factors. Several recent studies address these challenges by using school entry policies (see, e.g., McCrary \& Royer 2011) or changes in compulsory schooling laws (see, e.g., Black et al. 2008, Monstad et al. 2008, Silles 2011) as instruments for education. The evidence from these studies is mixed as we show in Table 2.

[Table 2 about here]

Studies for countries and population groups with higher levels of fertility generally find negative effects of education on fertility (see, e.g., Osili \& Long (2008) for Nigeria, Lavy \& Zablotsky (2011) for Arabs in Israel). Analyses based on compulsory schooling reforms in the U.S. and several European countries usually suggest that increased education leads to a postponement of the first birth away from teenage motherhood (see, e.g., Black et al. (2008) for the U.S. and Norway, Silles (2011) for Great Britain and Northern Ireland). However, increased education does not necessarily affect completed fertility because women can catch up an initial reduction in births at later ages (see, e.g., Monstad et al. (2008) for Norway, Fort (2009) for Italy, Geruso et al. (2011) for U.K.). McCrary \& Royer (2011) explore school entry rules in two U.S. states (California and Texas) and do not find any causal effect of education on fertility, neither on the incidence of motherhood, nor on the timing of first births. Recent contributions by Fort et al. (2011) and Braakmann (2011) present contradictory evidence from mandatory schooling reforms in Europe. ${ }^{7}$ Their results suggest that more education significantly increases the number of births. ${ }^{8}$ Inarguably, the estimated effects may differ across studies because education affects

\footnotetext{
7 The study closest to ours is Fort et al. (2011) which examines fertility in Europe using reforms to compulsory schooling from eight countries. However, this study considers only four German states which introduced the reform simultaneously in 1967.

8 The authors attribute their finding to a positive effect of education on the stability of marriages.
} 
fertility through several different channels, and the intensity of these channels may vary across countries, subpopulations, or levels of education.

As for Germany, the related literature on mothers' labor market outcomes indicates that the opportunity costs of child rearing are particularly high because the institutional framework hampers the compatibility of work and family life. West German mothers experience low coverage of public childcare services (see, e.g., D'Addio \& D'Ercole 2005, Wrohlich 2008). A considerable excess demand for subsidized childcare is related both to the highly regulated market for childcare (Evers et al. 2005) and to the high cost of private childcare alternatives (Wrohlich 2008). Furthermore, skepticism about the quality of public childcare (Blau \& Hagy 1998, Spieß \& Tietze 2002) and social attitudes against the employment of mothers (Hank et al. 2004) may increase the costs of childrearing in Germany. In addition, compared to mothers from other developed countries, German mothers experience relatively high wage losses due to child-related employment interruptions (Gangl \& Ziefle 2009). Cross-national comparisons of fiscal and parental leave policies conclude that the German institutional framework favors traditional "male bread-winner" families and encourages mothers to stay out of the labor market (at least temporarily), or to work part time (see, e.g., Sainsbury 1999, Geyer \& Steiner 2007, Dearing et al. 2007, Hanel \& Riphahn 2012).

Based on the above discussion, we test the hypothesis that education reduces fertility in West Germany. Specifically, given the German institutional context, we expect additional education to increase the probability of remaining childless and to reduce the number of births due to the increased opportunity costs of child rearing associated with an extra year of schooling. Furthermore, similar to other studies we expect that an extension of mandatory schooling generates a postponement of first births because education and childrearing are difficult to combine.

\section{Identification strategy}

Our identification strategy considers the following equations:

$$
y_{i}=\alpha \text { educ }_{i}+\operatorname{state}_{i}^{\prime} \theta+\operatorname{cohort}_{i}^{\prime} \varphi+\text { statetrend }_{i}^{\prime} \mu+z_{i}^{\prime} \pi+\epsilon_{i}
$$




$$
\text { educ }_{i}=\text { reform }_{i}+\text { state }_{i}^{\prime} \beta+\text { cohort }_{i}^{\prime} \gamma+\text { statetrend }_{i}^{\prime} \delta+z_{i}^{\prime} \lambda+\nu_{i}
$$

where the dependent variable $y_{i}$ in (1) represents different measures for woman i's fertility outcomes. We consider three fertility outcomes: the number of children ever born, the probability of remaining childless, and the age-specific probability of births. These outcomes are a function of years of education $\left(e d u c_{i}\right)$, state fixed effects $\left(\right.$ state $\left._{i}\right)$, cohort fixed effects $\left(\right.$ cohort $\left._{i}\right)$, state-specific cohort trends ( statetrend $_{i}$ ), and socio-demographic background variables $z_{i}$ such ad marital status and community size. ${ }^{9} \alpha, \theta, \varphi, \mu, \pi, \phi, \beta, \gamma, \delta, \lambda$ represent coefficients to be estimated, $\epsilon_{i}$ and $\nu_{i}$ are random error terms.

Estimating equation 1 by OLS is likely to yield biased estimates for the impact of education on fertility, because the error term $\epsilon_{i}$ may include unobserved characteristics such as family preferences or childhood experiences. These characteristics are correlated with both education and fertility. However, the direction of the bias in an OLS estimation of $\alpha$ is not clear.

We exploit exogenous changes in education caused by the compulsory schooling reform described in section 2 to identify the causal effect of education on fertility outcomes. In particular, we exploit the cross-regional and cross-time variation in education that result from a staggered implementation in German states within a 23-year period (1946-1969). In a two stage least squares approach we first estimate equation 2: years of education of individual i $\left(e d u c_{i}\right)$ are a function of an indicator for the reform status $\left(\right.$ reform $\left._{i}\right)$, which equals 1 if a woman was affected by the reform, and 0 otherwise. Equation 2 includes the same control variables as equation 1 .

Our identification strategy fails if the timing of the reform is correlated with fertility in the federal states. To mitigate this concern we include linear and squared state-specific cohort trends in birth cohorts, which should capture any smooth trends in fertility and schooling at the state level. Moreover, we include cohort fixed effects to account for any cohort-specific effects such as the availability of oral contraceptives. Finally, state fixed effects should capture state-specific differences such as religious affiliation which may have also influenced the timing of the reform.

\footnotetext{
9 If the data allows, we also control for women's family background, e.g., their own mothers' age of birth. Statespecific cohort trends are included both in linear and squared forms.
} 
Our identification strategy also fails if other fertility-relevant changes took place and affected the same birth cohorts as the schooling reform did. This is, however, quite unlikely since the overall responsibility for family policies lies with the federal government. Although the state governments enforce enacted laws or reforms and are free to extend these reforms (Gerlach 2010), any important family policy reform in the last 60 years such as the introduction of child benefits (Kindergeld) affected women in all states simultaneously. ${ }^{10}$

\section{Data}

We use data from two German surveys to examine the relationship between women's education and three fertility outcomes (Number of children, childlessness, and the age-specific probability of births): the German Microzensus (MZ), and the German Socio-Economic Panel (SOEP).

Our primary data source is the MZ, an annual survey of a one percent random sample of German households. ${ }^{11}$ We use the 2008 survey, which is the first survey providing information on the number of children ever born to female respondents. ${ }^{12}$ The key advantage of the MZ is its large sample size and low unit and item non-response rates. The main shortcoming of the data is the lack of information on children's birth year, the state where an individual went to school, and parental background.

The second data set used here is the SOEP, a longitudinal survey of private households, conducted annually since 1984 (Haisken-DeNew \& Frick 2005, Wagner et al. 2007). The SOEP overcomes several drawbacks of the MZ: first, it contains retrospective biographical information on childbearing and thus permits analyzing the timing of births. Second, the SOEP provides family background variables that may affect both education and fertility (e.g., the number of siblings, parental educational attainment, and parents' birth year). Finally, the data provide retrospective information on individuals' educational careers and the state where they went to

\footnotetext{
${ }^{10}$ Similarly, the health care system is governed at the federal level, so the timing of the introduction of the contraceptive pill was not state-specific. This applies also to the reimbursement of oral contraceptives by health insurances. Some health insurances operate only regionally (e.g., company health insurance funds), but to the best of our knowledge the timing of first reimbursements did not vary across health insurances. In addition, our results are robust to the exclusion of single states from the analysis which suggests that our results are not driven by particular states.

${ }^{11}$ The scientific use file includes 70 percent of the full data set.

${ }^{12}$ Previous waves provide information on the number of children living in the household at the time of the interview.
} 
school. The main shortcoming of the SOEP is its relatively small sample size. We use observations from all available survey years, 1984-2010, to obtain a sufficient number of women for the treatment and control groups. In particular, we consider only the first interview of a woman conducted after she has turned 40 years old.

We impose similar sample restrictions on both the MZ and SOEP data. Table 3 presents the details of our sample selection procedure.

\section{[Table 3 about here]}

We select native German women ${ }^{13}$ from eight out of ten (excluding Berlin) West German states. We exclude Schleswig-Holstein and Hamburg from the analysis because the first birth cohorts affected by the reform were 1932 and 1931, respectively, and the MZ 2008 only reports the fertility of women born after $1933 .{ }^{14}$ We extract those observations from the MZ, who were born up to 5 years before/after the first birth cohort affected by the reform as presented in Figure 2. As the small sample size of the SOEP does not allow us to use a 5-year time window around the first birth cohort affected by the reform, and we use a 7-year window instead. Ideally we would like to have direct information on the state where a woman went to school. However, the geographic location of the attended school is available only for a subsample in the SOEP. For the remaining observations we use the current state of residence as a proxy. ${ }^{15}$ We exclude women who graduated from a school in socialist East Germany from the sample. ${ }^{16}$

Neither of the two data sets report the exact number of completed years of schooling. Instead, we observe information about the highest secondary school degree, and women's postsecondary education and training. We construct years of schooling for Germany and assign the usual number of years taken for a particular educational route (see, e.g., Krueger \& Pischke 1995, Pischke \& von Wachter 2008). First, we use the state information, the year of birth, and

\footnotetext{
${ }^{13}$ We omit first and second generation immigrants.

${ }^{14}$ In addition, the information on the dates of reform implementation in Schleswig-Holstein vary across different sources (compare Leschinsky \& Roeder 1980, Pischke \& von Wachter 2008).

${ }^{15} \mathrm{~A}$ potential source for biased estimates may be regional mobility. If mobility is uncorrelated with the reform our results might be biased towards zero. If there was anticipation and thus selective migration, our results are biased upwards. We argue, in line with e.g., Pischke \& von Wachter (2008), that regional mobility in Germany is so low (see, e.g., Harhoff \& Kane 1997) that this should yield at most minor consequences for our estimates.

${ }^{16}$ The MZ allows us to identify women with specific school degrees that could have been obtained in the former East German states only. In a subsample of the SOEP we can identify those who attended school in the former GDR.
} 
information on the timing of the reform from Table 1 to determine whether an individual should have graduated after 8 or 9 years in the basic track. For the other tracks, we use the standard duration for graduating in this particular track. Finally, we incorporate the information on postsecondary education to calculate a measure of total number of years of education (Krueger \& Pischke 1995). We conclude our sample selection by omitting observations with less than 7 years of education, missing values on education or fertility variables. ${ }^{17}$

Our final MZ sample includes 17,428 women born 1938-1959. The SOEP sample includes 2,649 women born 1937-1961. Table 4 shows summary statistics for both data sources. The table splits women into those who were affected by the reform, and those who were not.

\section{[Table 4 about here]}

In general, the MZ and SOEP samples show similar patterns for educational attainment and our control variables; however, fertility outcomes differ between the datasets. While the MZ data show that women who were subject to the reform have on average fewer children and are more likely to remain childless, we observe no fertility differences between the treatment and control groups in the SOEP sample. Nevertheless, women affected by the reform are more likely to delay their first birth. Fertility variation by reform status may reflect differences in birth cohort and educational attainment. By definition of our sample selection rules, women affected by the reform are born later and, as expected, complete more years of education than women not affected by the reform. In both groups the number of years of education exceeds the mandated 8 or 9 years of schooling because notable shares of women obtain an additional degree or training.

Figure 3 and Figure 4 plot the raw data on fertility outcomes by reform status. Figure 3 reveals the overall trends of declining fertility and increasing incidence of childlessness for younger cohorts, with small differences between women affected and not affected by the reform. Figure 4 shows that women who are subject to the reform postpone their first birth beyond the early 20s, and are more likely to have their first child at older ages compared to women who are not subject to the reform. Further, women affected by the reform have fewer children up to

\footnotetext{
${ }^{17}$ We exclude individuals with 7 years of education because this is inconsistent with 8 years (or 9 after the reform) of compulsory schooling. However, inclusion of this small subsample into the analysis does not affect our main results.
} 
the age of 36 , but then they fully catch up, so that the completed fertility at the end of the fertile years is nearly identical in both groups.

\section{Results}

\subsection{Effect of education on the number of children and childlessness}

We first explore whether the formal introduction of the compulsory 9th grade is a valid instrument for women's education. Figure 5 plots the average number of years of education for the five birth cohorts before and after the reform using the $\mathrm{MZ}$ data. The graph reveals a general increase in education for younger cohorts, but indicates a discrete jump of roughly 0.85 years for the first birth cohort affected by the reform.

[Figure 5 about here]

We estimate equation 2 using the MZ sample and show the first-stage estimation results in Table 5. Columns 1 and 2 present the results obtained on the full sample, and columns 3 and 4 on the subsample of basic track graduates. Additionally, columns 5 and 6 give the effect of the reform on track choice. We present the coefficients obtained from two specifications: one includes only linear state-specific trends in birth cohort, the other one also squared trends. In addition, all regressions include state of residence-fixed effects, year of birth-fixed effects, and indicators for marital status and municipality size. We estimate standard errors clustered at the state-year of birth level throughout to deal with potential serial correlation and heteroscedasticity (80 clusters).

[Table 5 about here]

The first-stage estimation results in Table 5 confirm the graphic impression: the first-stage coefficient of the reform indicator obtained on the full sample is significant across all specifications and indicates that the reform increased women's education on average by about 0.65-0.75 years (columns 1 and 2). The magnitudes of our estimates are slightly larger than those reported by other studies exploiting the German school reform (see, e.g., Pischke \& von 
Wachter 2008, Siedler 2010, Kemptner et al. 2011, Piopiunik 2011). We argue that these differences result mainly from different sample restrictions. ${ }^{18}$ Consistent with previous studies, the first-stage coefficient is smaller than 1 in the full sample (columns 1 and 2). Several sources of measurement error can contribute to an attenuation of the reform indicator coefficient: first, the implementation of the additional grade may not have been immediate and in practice required several years until each school offered the mandatory ninth grade (Leschinsky \& Roeder 1980). Second, we do not have direct information on the state of school attendance, and random migration may bias our estimates towards zero. Furthermore, the year of birth does not perfectly determine whether the reform affected an individual because some women may have started primary school a year earlier or later than officially scheduled. However, measurement error in the instrument does not bias subsequent estimates unless it is systematically correlated with both the reform introduction and fertility outcomes, which is rather unlikely. The F-statistics of significance tests of the reform dummy in the first stage are greater than 10 across specifications and confirm the validity of the instrument.

An important assumption for a causal estimate of the local average treatment effect is monotonicity, i.e., that all individuals respond to the reform implementation in the same way (Imbens \& Angrist 1994). In this particular case, we assume that all women affected by the schooling reform extended their education, and that no woman reduced education (e.g., by attending basic track instead of middle track, or dropping-out). To test whether the reform affected track choice, we estimate the effect of the reform implementation on the probability of graduating from the basic track (columns 5 and 6 in Table 5). The coefficients are very small, negative and insignificant. Thus, consistent with previous findings, we do not find evidence that the reform affected track choice (see, e.g., Pischke \& von Wachter 2008, Kemptner et al. 2011, Piopiunik 2011). ${ }^{19}$

Table 6 reports our key results on the effect of education on the number of children and the probability of remaining childless estimated separately for the full sample (columns 1 and 2) and the subsample of basic track graduates (columns 3 and 4).

\section{[Table 6 about here]}

\footnotetext{
${ }^{18}$ For example, Pischke \& von Wachter (2008) analyze working females and males and drop all individuals with missing wages.

${ }^{19}$ Kemptner et al. (2011) conclude that also changes in the composition of students within tracks caused by the reform should be very small if the track choice is not affected.
} 
The OLS results indicate that an additional year of education is negatively correlated with the number of children (Panel A, first row) and positively associated with the probability of remaining childless (Panel B, first row). The OLS estimates are statistically significant at the $1 \%$ level across specifications, samples, and fertility outcomes. However, the OLS regressions do not account for possible selection into education. Since we are interested in a causal relationship we turn to the instrumental variables estimates.

The signs of the coefficients obtained by the instrumental variable (IV) approach are similar to those from the OLS regressions: education reduces the number of children (Panel A, second row) and increases the probability of never having children (Panel B, second row). However, the magnitude of the effect of education on fertility outcomes is substantially larger when controlling for possible endogeneity. ${ }^{20}$

Our main results are robust to changes in specification of state-specific birth cohort trends. However, we argue that squared trends better address the concern that the introduction of the reform could be correlated with trends in education and fertility. The coefficient obtained from our preferred specification (Panel A, column 2) suggests that on the margin, one year of additional education increases the probability of remaining childless by 5.1 percentage points. However, the effect of education on childlessness is smaller and not statistically significant in the basic track subsample (Panel A, column 4). ${ }^{21}$ The magnitude of the effect on the number of children also varies between the full sample and the basic track subsample (Panel B, columns 2 and 4). However, the coefficient is negative and significant throughout, and indicates that an additional year of education reduces fertility by at least 0.1 children.

\footnotetext{
${ }^{20}$ We obtain qualitatively similar results on the SOEP sample, but the estimates are imprecise because of the small sample size (see Table A.1 in the appendix). For the SOEP sample we select a 7-year window to prevent inconsistency due to a small sample size. The signs of coefficients obtained using a 5-year window remain the same, but the standard errors increase as well. Futhermore, the results for basic track graduates are similar to those obtained with the MZ data. Detailed results are available upon request.

${ }^{21}$ The differences between the full sample and the basic track subsample may be a result of other channels (e.g. health related knowledge, assortative mating, or opportunity costs) through which the reform affected education. We would expect to observe a more pronounced effect in the basic track subsample because basic track was directly affected by the reform. Monstad et al. (2008) argue that a schooling reform might have affected women such that they chose a different "life track" as they would have without the reform implementation. Furthermore, Lang \& Kropp (1986) show that under the signaling and screening hypothesis, compulsory attendance laws affect all educational groups. However, because of noisy IV estimates the differences in the effects between the basic track sample and the full sample are not significant.
} 


\subsection{Effect of education on the timing of births}

Table 7 presents the results for the analysis of the timing of the first birth. Using the SOEP data we estimate the effect of education on the probability of giving first birth at a given age, conditional on not already having a child. Thus, for example, women who gave their first birth between age 15 and 20 are omitted in the estimation for the age group 21-25, and the number of observations falls from 2,649 to 2,219. All regressions control for state of residence, year of birth, linear and quadratic state-specific trends in year of birth, marital status, age of the mother at the womans' birth, and municipality size.

\section{[Table 7 about here]}

The OLS estimations suggest that an increase in education is related to a reduced probability of first birth below the age of 30 and to an increase in fertility at the end of women's fertile period. However, the IV results yield different conclusions. The point coefficients suggest a positive effect of education on the probability of first birth only for the age group 26-30, but the coefficient is statistically insignificant. For the remaining age groups the coefficients indicate negative effects of increased education. As for women aged 15-20 the coefficient is significant at the $5 \%$ level and of a large magnitude: each additional year of education reduces the probability of first motherhood as a teenager by 5.7 percentage points. This is a considerable impact relative to the incidence of teenage childbearing in the full sample of 16 percent. The first stage Fstatistic of 16.83 indicates that a weak instrument is not a concern. Furthermore, we find a large and significant effect of education on the probability of the first birth at ages 31-35: a oneyear increase in education decreases the probability of first motherhood at ages 30-34 by 15.4 percentage points. The share of women giving birth in this age group is roughly 9 percent in the full sample. This large negative effect is accompanied by a zero effect for the subsequent age group and suggests that women in their early 30s are more likely to remain childless than to bear children later in life.

For completeness, we additionally incorporate the information on the timing of the subsequent births, i.e. estimate the effect of education on cumulative fertility at a given age. This cumulative fertility refers to the number of children born up to a specific age and we estimate 
the effect separately for one-year age intervals between 15 and 45 by 2SLS. All of these 31 regressions control for state of residence, year of birth, linear and quadratic state-specific trends in year of birth, marital status, and municipality size. Figure 6 summarizes the results obtained from these linear regressions.

[Figure 6 about here]

We plot the coefficients on education and 90\% confidence intervals around these point estimates by age. The IV estimates give the effect of education on the number of children born up to a given age. Figure 6 reveals more heterogeneity in the effects of education on teenage childbearing than Table 7. Specifically, we observe a positive coefficient for age 18, which could indicate a catch-up effect after graduation from school for the earlier loss in births resulting from "incarceration" by extended schooling. However, the effect at age 18 is statistically indistinguishable from zero. Figure 6 generally confirms fertility reduction in teenage years. The remaining coefficients indicate a negative effect of education on cumulative fertility throughout. Thus, the effect of education on completed fertility at each age is negative. In contrast to the findings for the U.K. by Geruso et al. (2011) who find an upward trend and a catch-up effect in births, for Germany the point estimates follow a downward trend, i.e., the fertility losses resulting from increased education become more severe with increasing age. While at several age-years after the teenage years the coefficients are insignificant and small, which could imply some catch-up effects. Starting at age 33 the effect of education on cumulative fertility is clearly negative and we reject a complete catch-up. The effect at age 45 is identical with the effect on the total number of children presented in section 6.1 and confirms that additional education leads to a permanent reduction in completed fertility.

Overall, our results suggest that the impact of increased education is to lower the number of children and to raise the probability of childlessness. Our findings for Germany contrast with the evidence for the U.S. and several West European countries (see, e.g., Black et al. 2008, Silles 2011, Monstad et al. 2008). These studies usually find that more education leads to a delay of the first birth beyond teenage years and to a later catch-up for the initial loss in births. However, up to now there is no evidence for developed countries suggesting that education causally reduces completed fertility. While birth postponement away from early 
motherhood in response to extended education may reflect a pure incarceration effect, reduced childbearing in the 30s may work through higher opportunity costs. This mechanism is consistent with the previous evidence suggesting that German women experience higher wage penalties for motherhood compared to women in other European countries (Gangl \& Ziefle 2009). Still, the question remains whether the reduced childbearing at older ages is driven by women's choice to remain childless, or by an age-related decline in fecundity.

\section{Robustness}

In this section we test whether our main results are robust to changes in the definition of the education variable and in sample selection criteria.

Our baseline results use the imputed years of education as a measure for women's educational attainment. We use the typical duration of attaining a specific degree and add postsecondary years of education. This educational variable has some disadvantages. For example, it does not consider information about repeated or skipped classes.

To check the robustness of our results we use an alternative variable called the "length of education". To construct this variable we use self-reported information about the graduation year and the assumption that all women entered primary school at age $6 .{ }^{22}$ Thus, "length of education" is given by the actual graduation year minus year of birth minus school entry age 6 (graduation year - year of birth - 6) and measures calendar years, not school years. To some extent this alternative variable captures skipped and repeated classes, and the short and long school years, which some states performed simultaneously to the extension of compulsory schooling (Pischke 2007). However, the "length of education" introduces noise because, for example, some women start school at age 7 . Such noise may bias our first-stage results towards zero, and leads to higher coefficients at the second stage.

\footnotetext{
${ }^{22}$ The major problem with this variable is potential measurement error in the self reported graduation year. Our sample size reduces to 12,657 observations if we use only reliable information from MZ. We classify information as reliable if the "length of schooling" was not more than up to two years longer or shorter than the standard duration needed to obtain a certain degree. The first-stage results are slightly affected by our definition of valid information. The wider the window the lower the first-stage coefficient and vice versa. The direction of the effect of education on the number of children and childlessness are robust. More detailed results are available upon request.
} 
[Table 8 about here]

Table 8 gives the IV results for the effect of education on fertility obtained by using the variable "length of education". ${ }^{23}$ Overall, the results reported before are robust: first-stage coefficients are below 1 across all specifications which may be driven by measurement error, the short school years, or measurement error in the timing of the reform. The values of the firststage F-statistics are lower than those presented in Table 6. In the full sample (columns 1 and 2) the significance of the results varies with the specification of the included trends in birth cohort, but the sign of the coefficient remains negative. Furthermore, the estimation on the sample of basic track graduates confirms our basic results (columns 3 and 4).

To test whether our results depend on our sample selection criteria, we replicate the results using different symmetric and asymmetric windows of birth cohorts around the first cohort affected by the reform. In the main analysis we use a symmetric window and follow Monstad et al. (2008) and Brunello et al. (2009) who argue that a symmetric approach guarantees similar sample sizes in treatment and control group by state and similar characteristics of the two groups. Furthermore, the estimation of the effect of education is on a more local level because a symmetric window excludes effects of other potential reforms and reduces the influence of unaccounted confounders (Brunello et al. 2009). The disadvantage of a symmetric window is a substantial reduction in sample size. An alternative approach is to use an asymmetric window, i.e., to include all individuals born between 1938 and 1959 (see, e.g., Pischke \& von Wachter 2008, Piopiunik 2011). We next estimate the effect of education on completed fertility and childlessness using different cohort windows around the reform: a 4 to 7 -year symmetric window, and an asymmetric window.

[Table 9 about here]

Table 9 shows that the choice of the window width may affect the magnitude of the effect, while the effect of education on the number of children remains negative. The first stage Fstatistic increases the wider the window and the larger the sample. The effect of education on fertility decreases the wider the window and the larger the sample. If we use a 7-year symmetric

\footnotetext{
${ }^{23}$ We are not able to carry out this robustness test on the SOEP sample because information on the year of graduation is available for a very small number of observations.
} 
window the effect remains negative, but the coefficient is insignificant. Furthermore, the effect of education on the probability of childlessness is robust to these changes in sample selection criteria.

We apply similar robustness checks for our main results on the timing of first births obtained with the SOEP sample and using a 7-year window. We repeat the regressions using alternative definition of the window around the first birth cohort affected by the reform. Table 10 gives the results on the probability of giving first birth in a given age group obtained with both a 5-year and a 9-year window.

\section{[Table 10 about here]}

The table reveals that the sample size decreases if we use a 5-year window, however, the results remain qualitatively the same. The magnitude and significance of the coefficients changes, but the direction of the effects on giving the first birth at a particular age conditioned on not already having a child remains unaffected. The results obtained using a 9-year window confirm our baseline results presented in Table 7 . The effect of education on giving a first birth at a given age is negative for age group 15-20. Consistent with the results obtained with the MZ sample, the effects are smaller for a wider window if we compare the 9-year and 7-year window.

\section{Conclusions}

We examine the effect of women's education on three fertility outcomes: number of children, probability of ultimate childlessness, and timing of births. We exploit a German schooling reform that extended compulsory education from 8 to 9 years, to identify the causal effect of one additional year of schooling on fertility. Our empirical approach takes advantage of the exogenous variation in the reform's timing across federal states and time.

We find that education generally increases the probability of remaining childless and reduces the number of children. In particular, one additional year of education raises the probability of childlessness by at least 2 percentage points. This effect is considerable compared to the average incidence of childlessness of almost 20 percent in the analyzed cohorts of women. The effect of education on the total number of children is also pronounced, as an additional year of education 
reduces the number of births per woman by more than 0.1 children. This decrease accounts for about 6 percent of average cohort-specific fertility. We show that our main findings are robust to changes in sample selection criteria and alternative definition of the education variable.

Consistent with causal evidence for other developed countries (see, e.g., Monstad et al. 2008, Grönqvist \& Hall 2011) our findings on the timing of births suggest that extended education leads to a birth postponement away from teenage motherhood and reduces the probability of giving subsequent births in the early 20s. Furthermore, additional education significantly lowers the probability of giving a first birth among women at ages 31-35. It may seem implausible that the extension of compulsory schooling by one year still affects women's choices in their 30s, but we argue that decreased childbearing in this age group may reflect higher opportunity costs, inflexibility of the labor market, or the age-related decline in fecundity.

In contrast to previous studies for developed countries, we find a negative causal effect of education on fertility. ${ }^{24}$ Our findings sharply contrast with the recent evidence for other European countries by Fort et al. (2011) and Braakmann (2011) who conclude that more education significantly increases the number of births. We interpret these different patterns for Germany mainly as the result of high opportunity costs of childrearing, compared to other countries. Specifically, our results are consistent with previous evidence suggesting that German mothers experience the highest wage penalty for motherhood in the Western world (Gangl \& Ziefle 2009). Gangl \& Ziefle (2009) find that the high permanent wage losses seem to be related to statistical discrimination against mothers in the German labor market. Several features of the institutional and cultural environment in Germany impede the compatibility of family and work, and thus may reinforce employers' discrimination against mothers. Most striking is the highly inflexible system of childcare which might account for the considerable excess demand for subsidized childcare (D'Addio \& D'Ercole 2005, Wrohlich 2008). Furthermore, extensive parental leave regulations and the tax system providing a "housewife bonus" favor traditional family types and reinforce attitudes in favor of mothers' non-involvement in the labor force (Gornick et al. 1998, Kreyenfeld 2004).

\footnotetext{
${ }^{24}$ The existing causal studies for the U.S. and several European countries usually suggests that extended education leads to postponement of first birth away from teenage motherhood, but does not affect completed fertility (see, e.g., Black et al. 2008, Monstad et al. 2008, Silles 2011).
} 
The evidence on the effect of education on fertility varies across countries. These differences may reflect institutional differences that affect women's opportunity costs of childbearing such as childcare provision rates, family policies or flexibility of the labor market. As for Germany, our results may be a consequence of institutional settings, labor market conditions, or social norms. We leave the exploration of cross-country differences in the effect of education on fertility for future research. 


\section{References}

Becker, G. (1965). A theory of the allocation of time, The Economic Journal 75(299): 493-517.

Becker, G., Duesenberry, J. \& Okun, B. (1960). An economic analysis of fertility, in G. G. Roberts (ed.), Demographic and Economic Change in Developed Countries: A Conference of the Universities - National Bureau Committee for Economic Research, 11, Princeton University Press, Princeton, pp. 209-231.

Becker, G. \& Lewis, H. (1973). On the interaction between the quantity and quality of children, Journal of Political Economy 81(2): 279-288.

Behrman, J. \& Rosenzweig, M. (2002). Does increasing women's schooling raise the schooling of the next generation?, The American Economic Review 92(1): 323-334.

Black, S., Devereux, P. \& Salvanes, K. (2008). Staying in the classroom and out of the maternity ward? The effect of compulsory schooling laws on teenage births, The Economic Journal 118(530): 1025-1054.

Blau, D. \& Hagy, J. (1998). The demand for quality in child care, Journal of Political Economy 106: $104-146$.

Braakmann, N. (2011). Female education and fertility-evidence from changes in British compulsory schooling laws, Newcastle Discussion Papers in Economics 2011/05, Newcastle University Business School.

Brunello, G., Fort, M. \& Weber, G. (2009). Changes in compulsory schooling, education and the distribution of wages in Europe, The Economic Journal 119(536): 516-539.

Charles, K. \& Luoh, M. (2003). Gender differences in completed schooling, Review of Economics and Statistics 85(3): 559-577.

D'Addio, A. C. \& D'Ercole, M. M. (2005). Trends and determinants of fertility rates in OECD countries: the role of policies, Social, Employment, and Migration Working Papers 27, OECD, Paris.

Dearing, H., Hofer, H., Lietz, C., Winter-Ebmer, R. \& Wrohlich, K. (2007). Why are mothers working longer hours in Austria than in Germany? A comparative microsimulation analysis, Fiscal Studies 28(4): 463-495.

Dustmann, C. (2004). Parental background, secondary school track choice, and wages, Oxford Economic Papers 56: 209-230.

Evers, A., Lewis, J. \& Riedel, B. (2005). Developing child-care provision in England and Germany: problems of governance, Journal of European Social Policy 15: 195-209.

Federal Bureau of Statistics (2007). Geburten in Deutschland, Statistisches Bundesamt, Wiesbaden.

Fort, M. (2009). New evidence on the causal impact of education on fertility, EEA-ESEM 2009 Congress WP.

Fort, M., Schneeweis, N. \& Winter-Ebmer, R. (2011). More schooling, more children: compulsory schooling reforms and fertility in Europe, IZA Discussion Paper 2693, IZA, Bonn. 
Gangl, M. \& Ziefle, A. (2009). Motherhood, labor force behavior, and women's careers: an empirical assessment of the wage penalty for motherhood in Britain, Germany, and the United States, Demography 46(2): 341-369.

Gerlach, I. (2010). Familienpolitik, 2 edn, VS Verlag für Sozialwissenschaften, Wiebaden.

Geruso, M., Clark, D. \& Royer, H. (2011). The impact of education on fertility: Quasiexperimental evidence from the UK. mimeo, Princeton, Princeton University.

Geyer, J. \& Steiner, V. (2007). Short-run and long-term effects of childbirth on mothers' employment and working hours across institutional regimes: an empirical analysis based on the European Community Household Panel, Discussion Paper 2693, IZA, Bonn.

Gornick, J. C., Meyers, M. K. \& Ross, K. E. (1998). Public policies and the employment of mothers: a cross-national study, Social Science Quarterly 79(1): 35-54.

Grönqvist, H. \& Hall, C. (2011). Education policy and early fertility: lessons from an expansion of upper secondary schooling, Working Paper Series 24, IFAU - Institute for Labour Market Policy Evaluation.

Grossman, M. (1972). On the concept of health capital and the demand for health, The Journal of Political Economy 80(2): 223-255.

Haisken-DeNew, J. \& Frick, J. (2005). Desktop Companion to the German Socio-Economic Panel (SOEP), DIW, Berlin.

Hanel, B. \& Riphahn, R. T. (2012). The employment of mothers - recent developments and their determinants in East and West Germany, Jahrbücher für Nationalökonomie und Statistik (Journal of Economics and Statistics) 232(2): 146-176.

Hank, K., Kreyenfeld, M. \& Spieß, C. K. (2004). Kinderbetreuung und Fertilität in Deutschland, Zeitschrift für Soziologie 33(3): 228-244.

Harhoff, D. \& Kane, T. J. (1997). Is the German apprenticeship system a panacea for the U.S. labor market?, Journal of Population Economics 10(2): 171-196.

Imbens, G. W. \& Angrist, J. D. (1994). Identification and estimation of local average treatment effects, Econometrica 62(2): 467-475.

Jürges, H. \& Schneider, K. (2007). What can go wrong will go wrong: birthday effects and early tracking in the German school system, CESIfo Working Paper 2055, CESifo, Munich.

Kemptner, D., Jürges, H. \& Reinhold, S. (2011). Changes in compulsory schooling and the causal effect of education on health: evidence from Germany, Journal of Health Economics 30(2): 340 - 354 .

KMK (2010a). Übergang von der Grundschule in Schulen des Sekundarbereichs I und Förderung, Beobachtung und Orientierung in den Jahrgangsstufen 5 und 6 (sog. Orientierungsstufe), Informationsschrift des Sekretariats der Kultusministerkonferenz.

URL: http://www.kmk.org/bildung-schule/allgemeine-bildung/uebersicht-schulsystem. html 
KMK (2010b). The Education System in the Federal Republic of Germany 1999. A Description of Responsibilities, Structures and Developments in Education Policy for the Exchange of Information in Europe, Secretariat of the Standing Conference of the Ministers of Education and Cultural Affairs of the Länder in the Federal Republic of Germany, Bonn.

Kreyenfeld, M. (2004). Fertility decisions in the FRG and GDR: an analysis with data from the German Fertility and Family Survey, Demographic Research S3(11): 275-318.

Krueger, A. \& Pischke, J.-S. (1995). A comparison of East and West German labor markets before and after unification, in L. F. H. Freeman, R. B. \& Katz (ed.), Differences and Changes in Wage Structures, University of Chicago Press, Chicago, pp. 405-445.

Lang, K. \& Kropp, D. (1986). Human capital versus sorting: The effects of compulsory attendance laws, The Quarterly Journal of Economics 101(3): 609-624.

Lappegård, T. \& Rønsen, M. (2005). The multifaceted impact of education on entry into motherhood, European Journal of Population 21(1): 31-49.

Lavy, V. \& Zablotsky, A. (2011). Mother's schooling, fertility, and children's education: evidence from a natural experiment, NBER Working Paper w16856, National Bureau of Economic Research (NBER), Cambridge.

Leschinsky, A. \& Roeder, P. M. (1980). Didaktik und Unterricht in der Sekundarschule I seit 1950 - Entwicklung der Rahmenbedingungen, in P. B. Max-Planck-Institut für Bildungsforschung (ed.), Bildung in der Bundesrepublik Deutschland - Daten und Analysen, Band 1: Entwicklungen seit 1950, Klett-Cotta, Stuttgart, chapter 4, pp. 283-392.

McCrary, J. \& Royer, H. (2011). The effect of female education on fertility and infant health: evidence from school entry policies using exact date of birth, American Economic Review 101(1): 158-195.

Monstad, K., Propper, C. \& Salvanes, K. G. (2008). Education and fertility: evidence from a natural experiment, Scandinavian Journal of Economics 110(4): 827-852.

OECD (2011). OECD family database. Assessed [30. Jan. 2012].

URL: http://www.oecd.org/document/4/0,3746,en_2649_34819_37836996_1_1_1_1,00. html

Osili, U. \& Long, B. (2008). Does female schooling reduce fertility? Evidence from Nigeria, Journal of Development Economics 87(1): 57-75.

Petzold, H.-J. (1981). Schulzeitverlängerung: Parkplatz oder Bildungschance? Die Funktion des 9. und 10. Schuljahres, Päd.-Extra-Buchverlag, Bensheim.

Piopiunik, M. (2011). Intergenerational transmission of education and mediating channels: evidence from compulsory schooling reforms in Germany, Ifo Working Paper 107, CESifo, Munich.

Pischke, J.-S. (2007). The impact of length of the school year on student performance and earnings: evidence from the German short school years, The Economic Journal 117(523): 1216-1242. 
Pischke, J.-S. \& von Wachter, T. (2008). Zero returns to compulsory schooling in Germany: evidence and interpretation, The Review of Economics and Statistics 90(3): 592-598.

Rosenzweig, M. \& Schultz, T. (1989). Schooling, information and nonmarket productivity: contraceptive use and its effectiveness, International Economic Review 30(2): 457-477.

Sainsbury, D. (1999). Gender and welfare state regimes, Oxford University Press, USA.

Siedler, T. (2010). Schooling and citizenship in a young democracy: evidence from postwar Germany, Scandinavian Journal of Economics 112(2): 315-338.

Silles, M. (2011). The effect of schooling on teenage childbearing: evidence using changes in compulsory education laws, Journal of Population Economics 24(2): 761-777.

Spieß, C. K. \& Tietze, W. (2002). Qualitätssicherung in Kindertageseinrichtungen Gründe, Anforderungen und Umsetzungsüberlegungen für ein Gütesiegel, Zeitschrift für Erziehungswissenschaften 5: 139-162.

Wagner, G. G., Frick, J. R. \& Schupp, J. (2007). The German socio-economic panel study (SOEP) - scope, evolution and enhancements, Schmollers Jahrbuch 127(1): 139-169.

Willis, R. (1973). A new approach to the economic theory of fertility behavior, The Journal of Political Economy 81(2): 14-64.

Wrohlich, K. (2008). The excess demand for subsidized child care in Germany, Applied Economics 40(10): 1217-1228. 
Figure 1: Cohort share of graduates by school degree and birth year

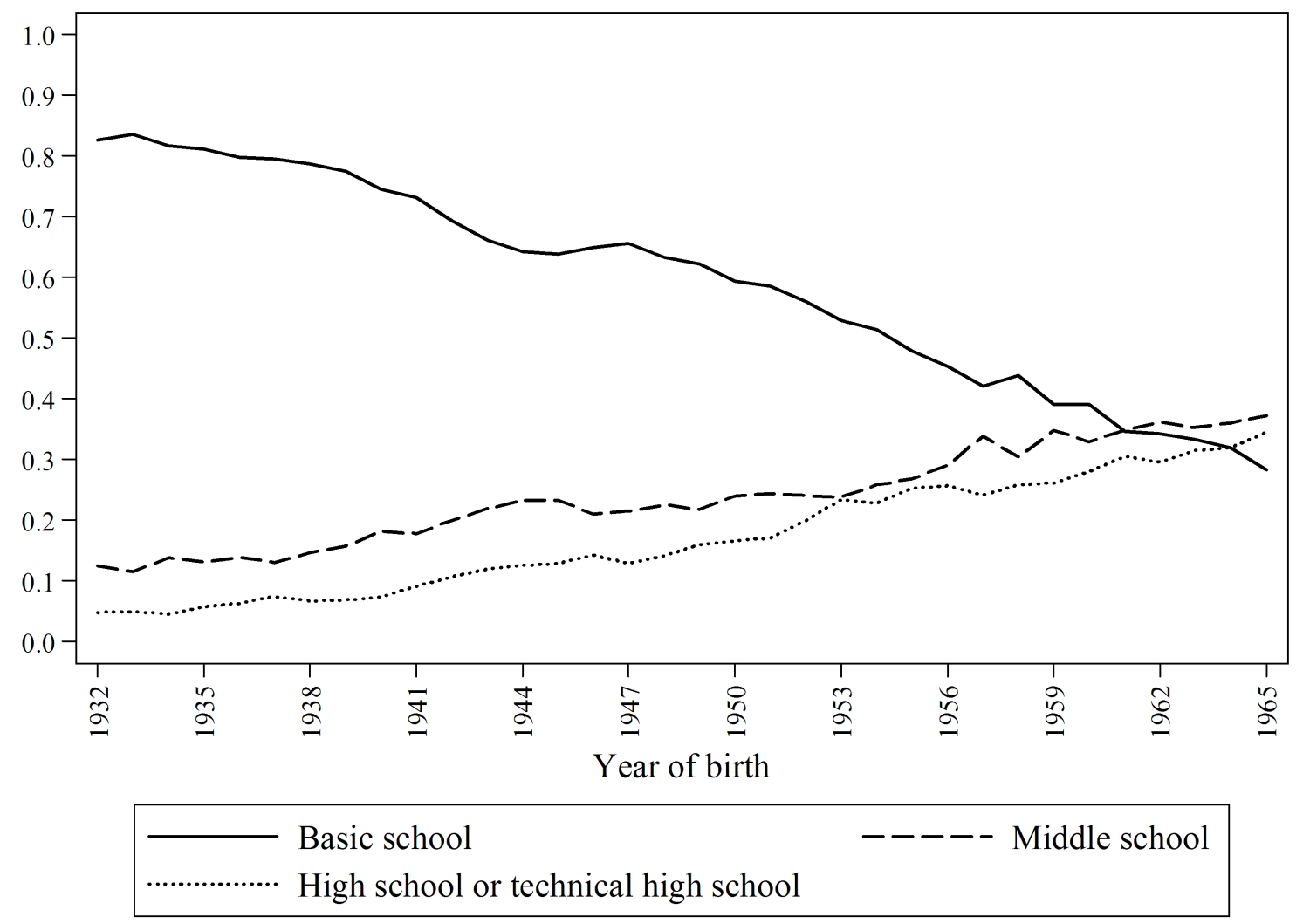

Source: German Mikrozensus (MZ) 2008; own calculations. 
Figure 2: Analyzed birth cohorts by federal state and reform status

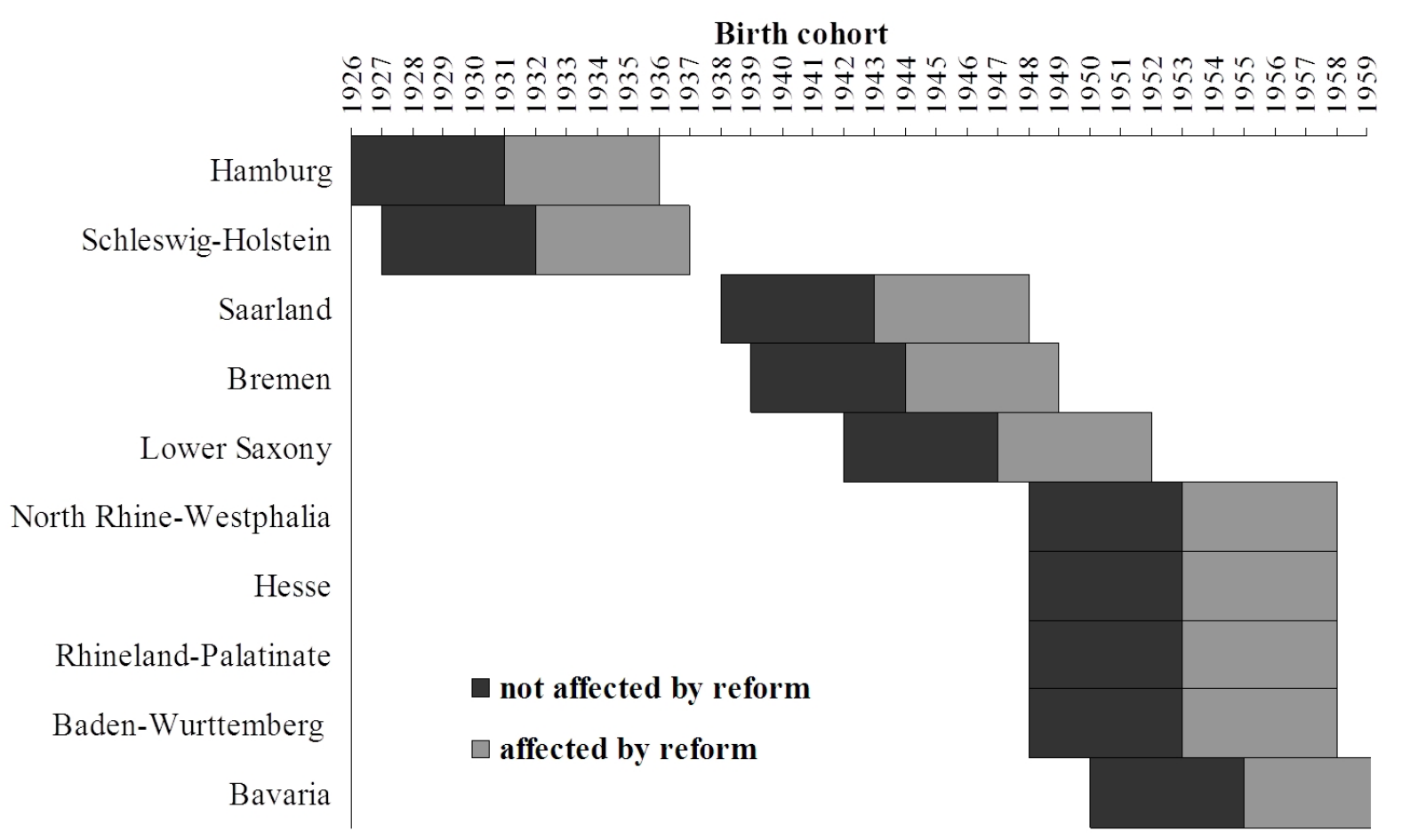

Note: We exclude Schleswig-Holstein and Hamburg from the analysis because the MZ 2008 reports fertility only for women born later than 1933 .

Source: Leschinsky \& Roeder (1980); own illustration. 
Figure 3: Fertility outcomes by birth cohort and reform status

a) Mean number of children

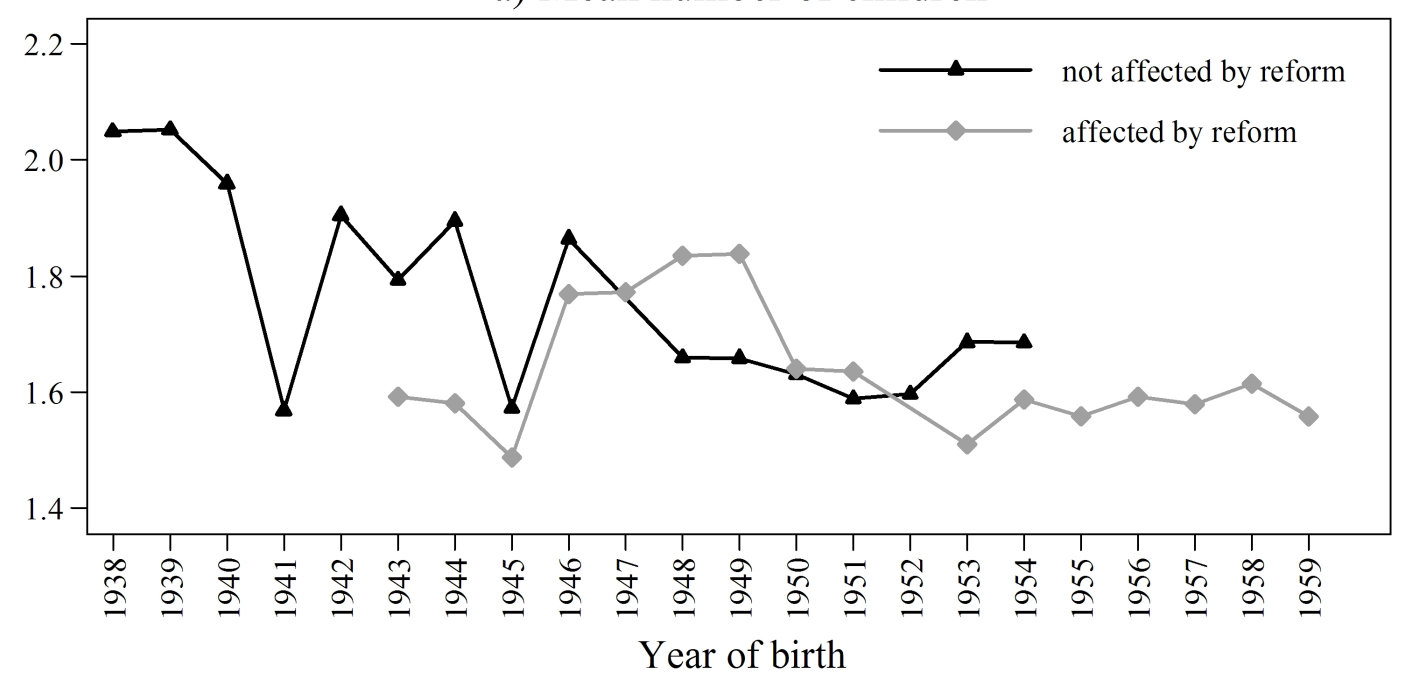

b) Mean probability of childlessness

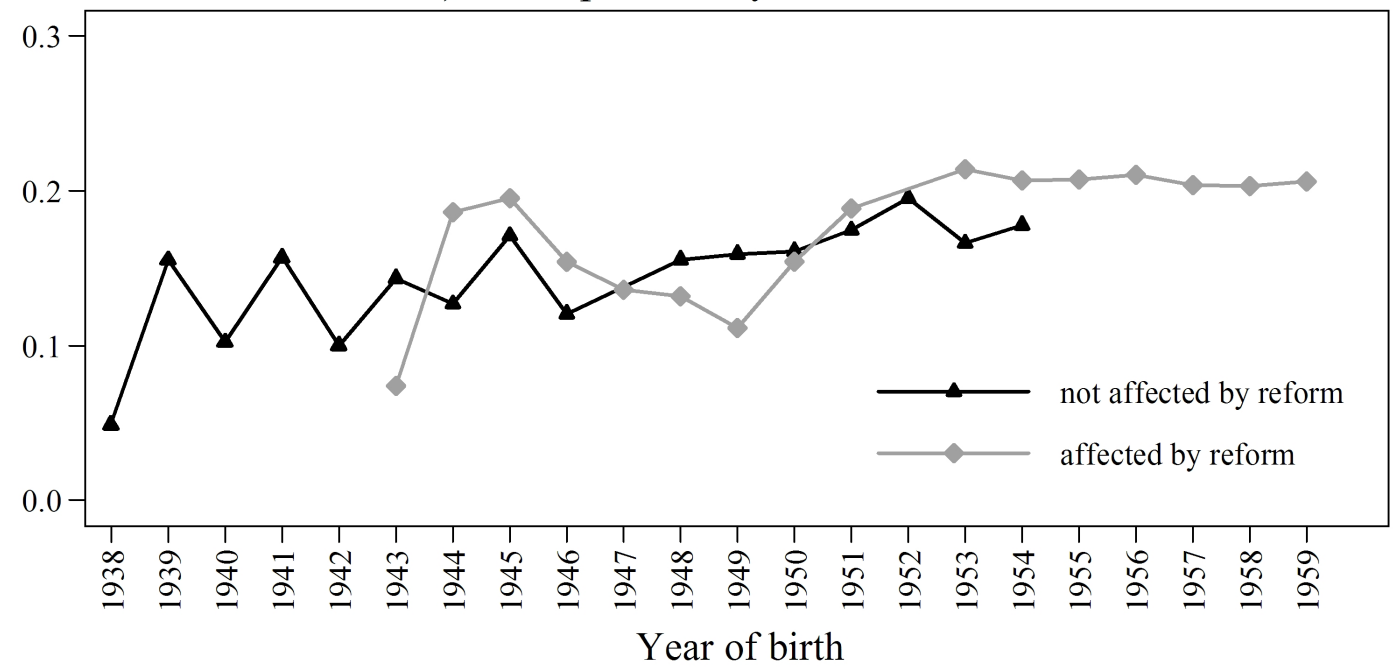

Note: The plots present unweighted raw data.

Source: German Mikrozensus (MZ) 2008; own calculations. 
Figure 4: Timing of births by age and reform status

a) Mean probability of first birth at a given age

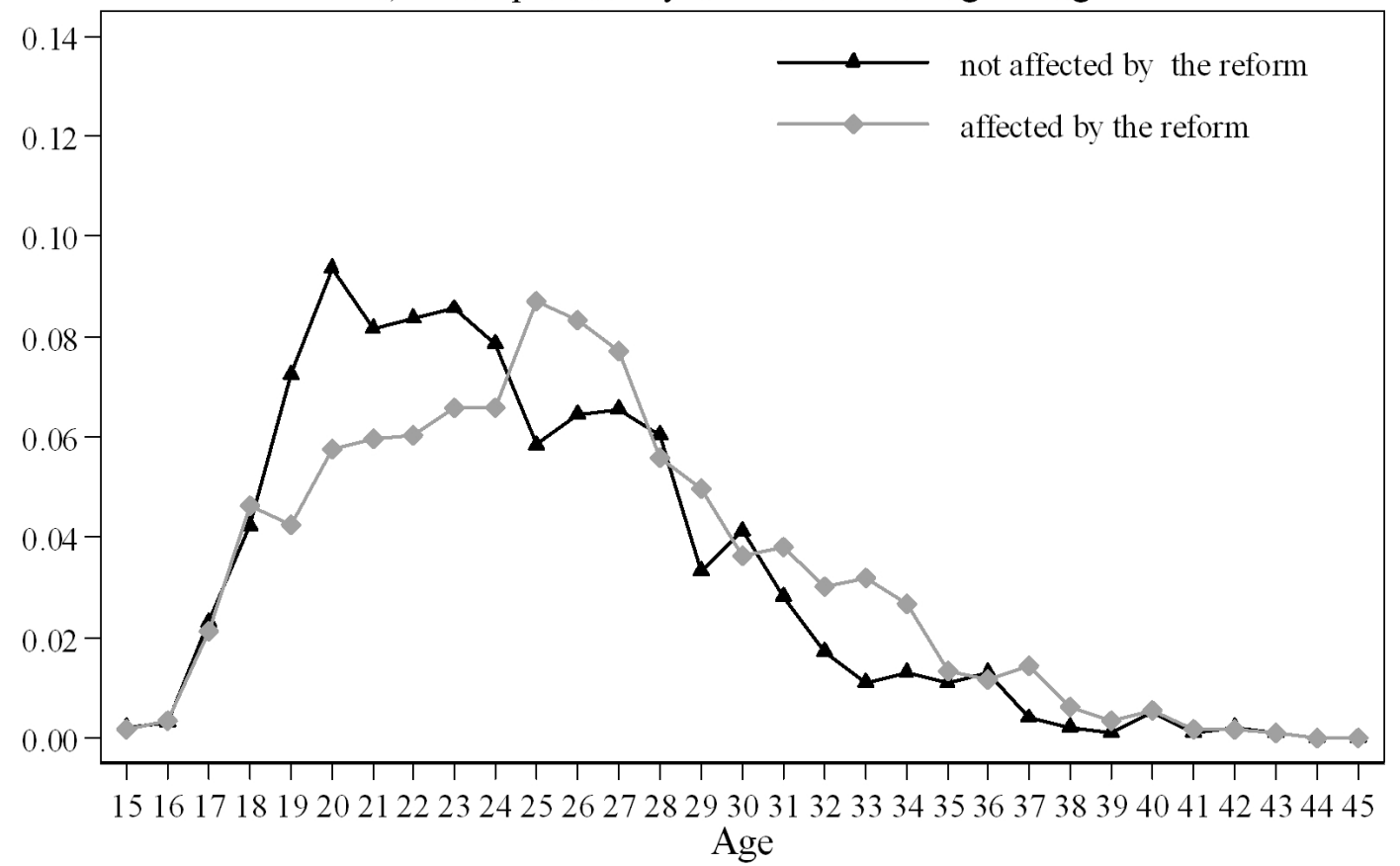

b) Mean number of children at a given age

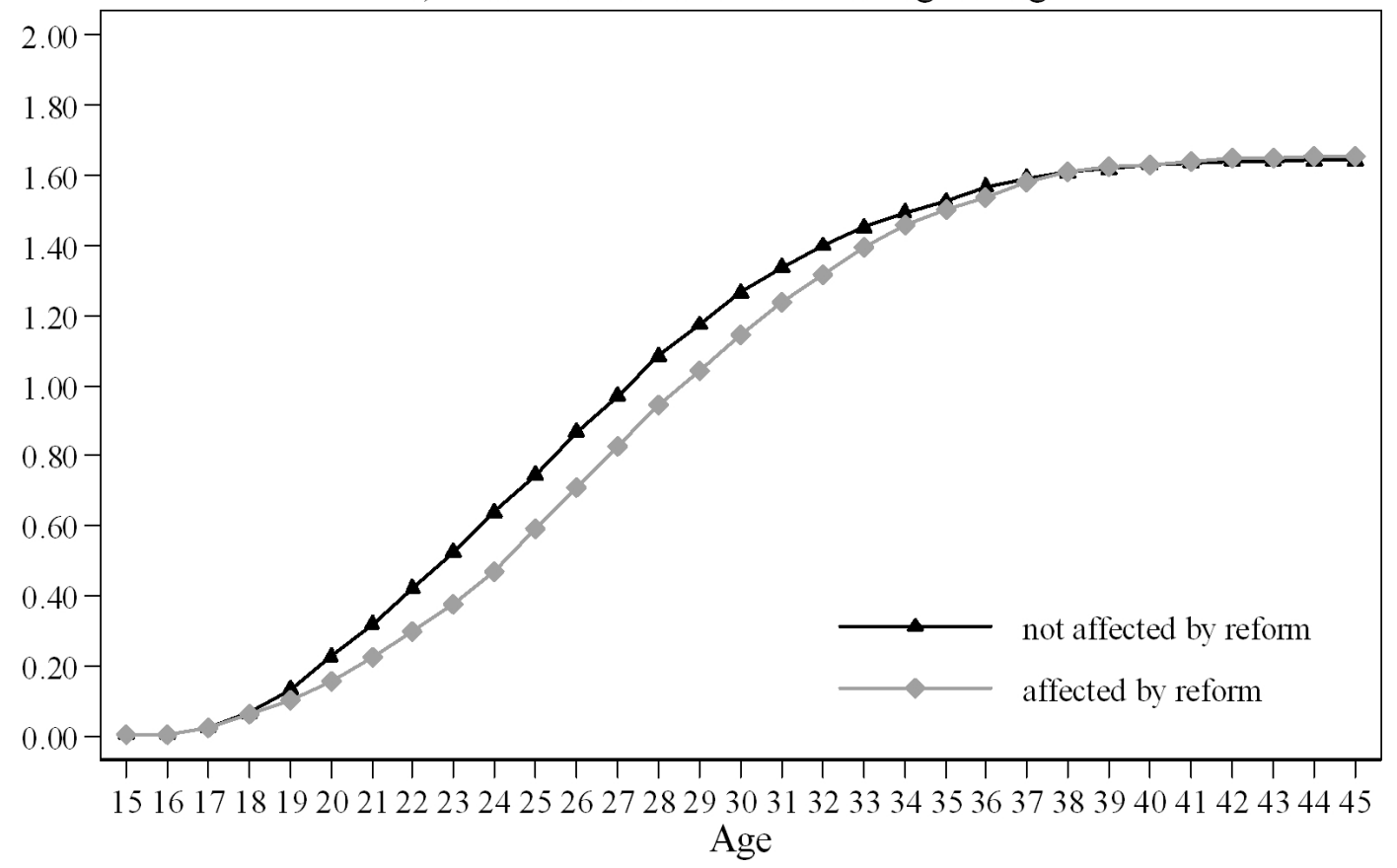

Note: The plots present unweighted raw data.

Source: SOEP 1984-2010; own calculations. 
Figure 5: First stage: effect of the reform on years of education

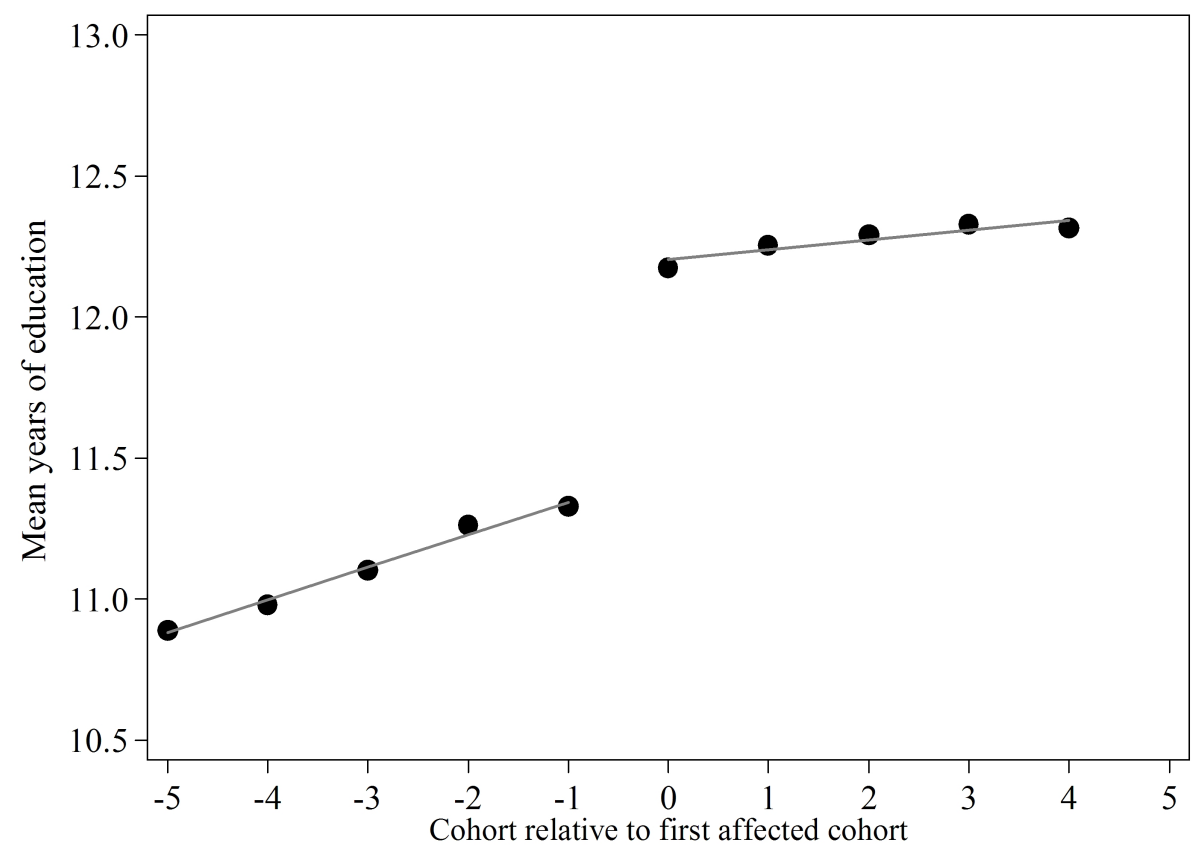

Note: The plot presents unweighted raw data.

Source: German Mikrozensus (MZ) 2008; own calculations. 
Figure 6: The effect of education on cumulative fertility at a given age

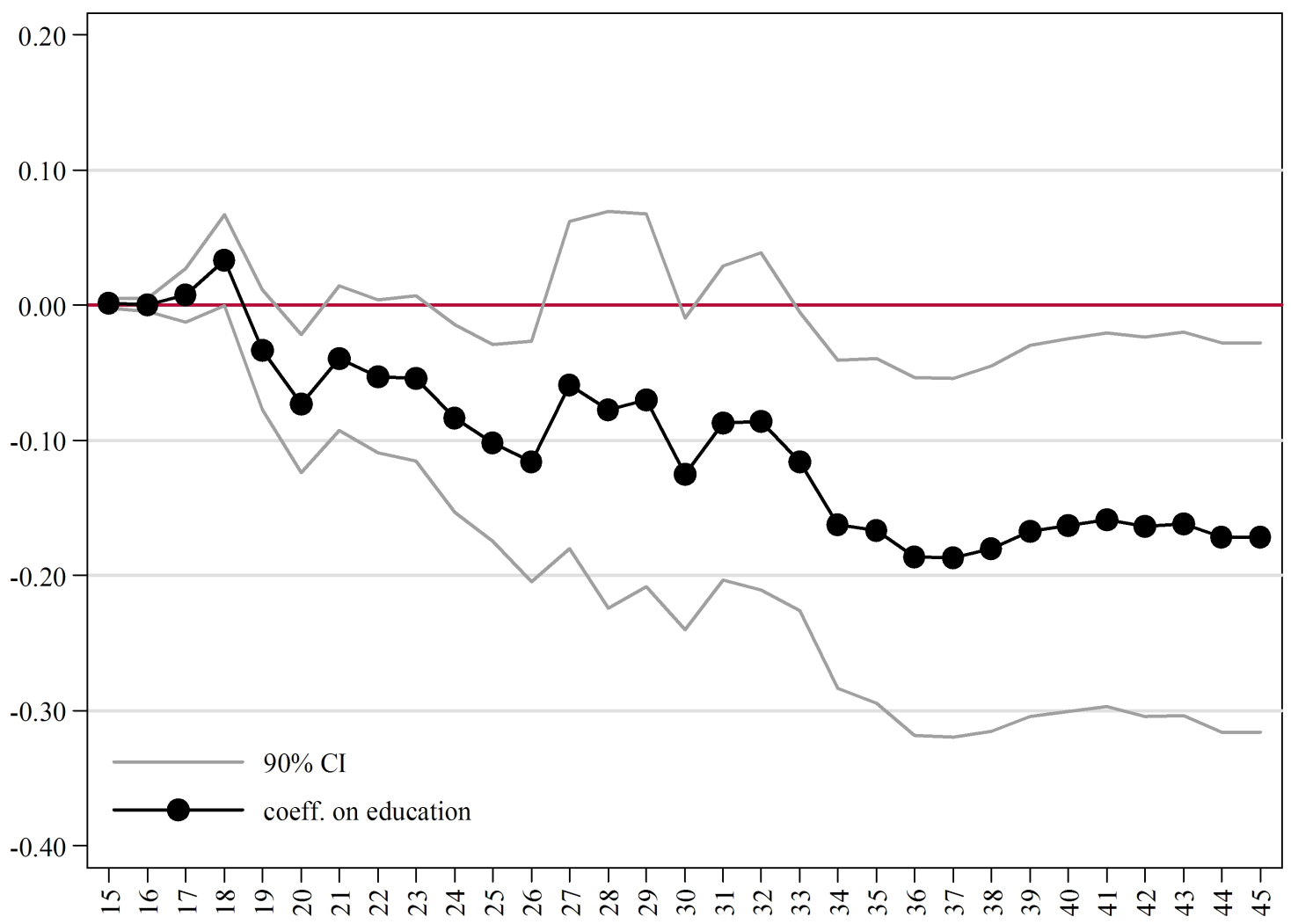

Note: Dependent variable is the number of children at a given age. Each dot presents a coefficient on education obtained from a separate linear regression. Grey lines are $90 \%$ confidence intervals around the point estimate. All regressions include state of residence-fixed effects, year of birth-fixed effects, squared state-specific trends in year of birth, indicators for marital status, municipality size, and mothers' age at the first birth.

Source: SOEP 1984-2010; own calculations. 
Table 1: Introduction of the 9th grade in compulsory schooling

\begin{tabular}{lcc}
\hline Federal state & $\begin{array}{c}\text { First school year with } \\
\text { compulsory 9 years }\end{array}$ & $\begin{array}{c}\text { First birth cohort with } \\
\text { compulsory 9 years }\end{array}$ \\
\hline Hamburg & 1946 & 1931 \\
Schleswig-Holstein & 1947 & 1932 \\
Saarland & 1958 & 1943 \\
Bremen & 1959 & 1944 \\
Lower Saxony & 1962 & 1947 \\
North Rhine-Westphalia & 1967 & 1953 \\
Hesse & 1967 & 1953 \\
Rhineland-Palatinate & 1967 & 1953 \\
Baden-Wurttemberg & 1967 & 1953 \\
Bavaria & 1969 & 1955 \\
\hline
\end{tabular}

Note: Year of the introduction of the 9th grade in secondary schooling in West Germany and the first affected birth cohort.

Source: Leschinsky \& Roeder (1980). 
Table 2: Empirical evidence on the effect of education on fertility

\begin{tabular}{llcl}
\hline Dependent variable & $\begin{array}{c}\text { Number of } \\
\text { children }\end{array}$ & Age of first birth & Country \\
\hline Osili \& Long (2008) & negative & & Nigeria \\
Lavy \& Zablotsky (2011) & negative & & Arabs in Israel \\
Fort (2009) & no effect & positive & Italy \\
Monstad et al. (2008) & no effect & positive & Sweden \\
Grönqvist \& Hall (2011) & no effect & no effect & U.S. \\
McCrary \& Royer (2011) & no effect & & Europe \\
Fort et al. (2011) & positive & & Great Britain \\
Braakmann (2011) & positive & positive & U.S. and Norway \\
Black et al. (2008) & & positive & Great Britain and Northern Ireland \\
Silles (2011) & & & \\
\hline
\end{tabular}

Note: Listed studies analyze the effect of education on the number of children and/or the effect of education on the timing of the first birth. All studies address the endogeneity of schooling e.g., by using school reforms as an instrument for education. 
Table 3: Data selection

Number of observations

MZ

SOEP

Women from eight West German states

born 5-years before/after the first affected birth cohort

20,054

born 7-years before/after the first affected birth cohort

- $\quad 2,708$

Information on state of education available

- $\quad 1,328$

Excluded because education in former East German states

251

13

Excluded because education $<7$ years or missing

263

45

Excluded because missing fertility information

2,112

1

Sample size

17,428

2,649

Source: German Mikrozensus (MZ) 2008 and SOEP 1984-2010; own calculations. 
Table 4: Sample means by reform status

\begin{tabular}{lrrrr}
\hline \multirow{2}{*}{ Variable } & \multicolumn{2}{c}{ MZ } & \multicolumn{2}{c}{ SOEP } \\
\hline Year of birth & not affected & affected & not affected & affected \\
\multirow{2}{*}{ Number of children } & 1949.46 & 1954.53 & 1948.54 & 1955.80 \\
& $(3.12)$ & $(3.08)$ & $(3.36)$ & $(3.09)$ \\
Childless & 1.66 & 1.59 & 1.64 & 1.66 \\
& $(1.12)$ & $(1.16)$ & $(1.16)$ & $(1.20)$ \\
Probability of giving first birth at age & 0.16 & 0.20 & 0.20 & 0.20 \\
$15-20$ & $(0.37)$ & $(0.40)$ & $(0.40)$ & $(0.40)$ \\
& & & & \\
$21-25$ & - & - & 0.19 & 0.14 \\
& - & - & $(0.39)$ & $(0.35)$ \\
$26-30$ & - & - & 0.31 & 0.27 \\
$31-35$ & - & - & $(0.46)$ & $(0.44)$ \\
& - & - & 0.21 & 0.24 \\
$>35$ & - & - & $0.41)$ & $(0.43)$ \\
& - & - & 0.06 & 0.11 \\
Years of education & - & - & $0.25)$ & $(0.32)$ \\
& - & - & $(0.15)$ & $(0.19)$ \\
Attended (0/1) basic track: 8th or 9th grade & $(2.91)$ & $(2.77)$ & 11.63 & 12.90 \\
& 0.63 & 0.51 & $(3.23)$ & $(2.98)$ \\
& $(0.48)$ & $(0.50)$ & 0.56 & 0.41 \\
Number of observations & 8,399 & 9,029 & 1,242 & 1,407 \\
\hline
\end{tabular}

Note: Standard deviations in parentheses. Samples are not weighted.

Source: German Mikrozensus (MZ) 2008 and SOEP 1984-2010; own calculations. 
Table 5: First stage results and the effect on track choice

\begin{tabular}{|c|c|c|c|c|c|c|}
\hline & \multicolumn{6}{|c|}{ Dependent variable } \\
\hline & \multicolumn{4}{|c|}{ Years of education } & \multirow{2}{*}{\multicolumn{2}{|c|}{$\frac{\text { Probability attend basic track }}{\text { Full sample }}$}} \\
\hline & \multicolumn{2}{|c|}{ Full sample } & \multicolumn{2}{|c|}{ Basic track } & & \\
\hline & (1) & (2) & (3) & (4) & (5) & (6) \\
\hline \multirow[t]{2}{*}{ Reform dummy } & $0.744 * * *$ & $0.647 * * *$ & $1.040 * * *$ & $1.090 * * *$ & -0.027 & -0.009 \\
\hline & $(0.080)$ & $(0.132)$ & $(0.042)$ & $(0.053)$ & $(0.020)$ & $(0.026)$ \\
\hline F-Statistic & 85.56 & 23.89 & 607.54 & 414.90 & 1.46 & 0.12 \\
\hline \multicolumn{7}{|c|}{ State-specific trends in year of birth } \\
\hline \multicolumn{7}{|l|}{ Linear } \\
\hline \multicolumn{7}{|l|}{ Squared } \\
\hline Observations & \multicolumn{2}{|c|}{17,428} & \multicolumn{2}{|c|}{9,918} & \multicolumn{2}{|c|}{17,428} \\
\hline
\end{tabular}

Notes: Each coefficient represents a separate linear regression. The F-Statistic gives the result of a significance test of the reform dummy in corresponding regressions. All regressions include state of residence-fixed effects, year of birth-fixed effects, state-specific trends (linear and quadratic) in year of birth, indicators for marital status and municipality size. Standard errors in parentheses are adjusted for clusters at the state-birth year level. ***, ** and $*$ indicate statistical significance at the $1 \%, 5 \%$ and $10 \%$ level.

Source: German Mikrozensus (MZ) 2008; own calculations. 
Table 6: Baseline results: the effect of education on fertility

\begin{tabular}{|c|c|c|c|c|}
\hline & \multicolumn{2}{|c|}{ Full sample } & \multicolumn{2}{|c|}{ Basic track } \\
\hline & (1) & (2) & (3) & (4) \\
\hline \multicolumn{5}{|c|}{ Panel A: Number of children } \\
\hline OLS & $\begin{array}{l}-0.020 * * * \\
(0.003)\end{array}$ & $\begin{array}{l}-0.020 * * * \\
(0.003)\end{array}$ & $\begin{array}{l}-0.134 * * * \\
(0.012)\end{array}$ & $\begin{array}{l}-0.133 \text { *** } \\
0.012\end{array}$ \\
\hline IV & $\begin{array}{l}-0.146 * * * \\
(0.035)\end{array}$ & $\begin{array}{l}-0.172 * * * \\
(0.050)\end{array}$ & $\begin{array}{l}-0.117 * * * \\
(0.043)\end{array}$ & $\begin{array}{l}-0.101 * \\
(0.057)\end{array}$ \\
\hline \multicolumn{5}{|c|}{ Panel B: Childlessness } \\
\hline OLS & $\begin{array}{l}0.010 * * * \\
(0.001)\end{array}$ & $\begin{array}{l}0.010 * * * \\
(0.001)\end{array}$ & $\begin{array}{l}0.016 * * * \\
(0.003)\end{array}$ & $\begin{array}{l}0.015 \text { *** } \\
(0.004)\end{array}$ \\
\hline IV & $\begin{array}{l}0.060 * * * \\
(0.013)\end{array}$ & $\begin{array}{l}0.051 \text { *** } \\
(0.018)\end{array}$ & $\begin{array}{l}0.050 * * * \\
(0.012)\end{array}$ & $\begin{array}{r}0.020 \\
(0.015)\end{array}$ \\
\hline \multicolumn{5}{|c|}{ State-specific trends in year of birth } \\
\hline $\begin{array}{l}\text { Linear } \\
\text { Squared }\end{array}$ & & $\begin{array}{l}\sqrt{ } \\
\sqrt{ }\end{array}$ & $\sqrt{ }$ & $\begin{array}{l}\sqrt{ } \\
\mathfrak{J}\end{array}$ \\
\hline Observations & & & & \\
\hline
\end{tabular}

Notes: Each coefficient represents a separate linear regression. All regressions include state of residence-fixed effects, year of birth-fixed effects, state-specific trends (linear and quadratic) in year of birth, indicators for marital status and municipality size. Standard errors in parentheses are adjusted for clusters at the state-birth year level. $* * *, * *$ and $*$ indicate statistical significance at the $1 \%, 5 \%$ and $10 \%$ level.

Source: German Mikrozensus (MZ) 2008; own calculations. 
Table 7: Baseline results: the effect of education on the age-specific probability of first birth

\begin{tabular}{llllll}
\hline Age at first birth & $15-20$ & $21-25$ & $26-30$ & $31-35$ & $>35$ \\
\hline OLS & $-0.028^{* * *}$ & $-0.036^{* * *}$ & $-0.008^{* *}$ & $0.022^{* * *}$ & $0.009^{*}$ \\
& $(0.002)$ & $(0.003)$ & $(0.003)$ & $(0.005)$ & $(0.005)$ \\
& & & & & \\
IV & $-0.057^{* *}$ & -0.052 & 0.048 & $-0.154^{*}$ & -0.045 \\
& $(0.022)$ & $(0.034)$ & $(0.045)$ & $(0.079)$ & $(0.081)$ \\
\hline First-stage results & & & & & \\
Reform dummy & $1.638^{* * *}$ & $1.396^{* * *}$ & $1.451^{* * *}$ & $1.458^{* * * *}$ & $0.989^{*}$ \\
First stage F-statistic & $(0.399)$ & $(0.407)$ & $(0.385)$ & $(0.461)$ & $(0.539)$ \\
\hline Observations & 16.83 & 11.76 & 14.20 & 10.00 & 3.38 \\
\hline
\end{tabular}

Note: Probability of giving the first birth at a given age, conditioned on not already having a child. Each coefficient represents a separate linear regression. All regressions include state of residence-fixed effects, year of birth-fixed effects, squared state-specific trends in year of birth, indicators for marital status, municipality size, and mothers' age at birth. Standard errors in parentheses are adjusted for clusters at the state-birth year level. ***, ** and * indicate statistical significance at the $1 \%, 5 \%$ and $10 \%$ level.

Source: SOEP 1984-2010; own calculations. 
Table 8: The effect of education on childlessness and the number of children - alternative definition of the education variable

\begin{tabular}{|c|c|c|c|c|}
\hline & \multicolumn{2}{|c|}{ Full sample } & \multicolumn{2}{|c|}{ Basic track } \\
\hline & (1) & (2) & (3) & (4) \\
\hline \multicolumn{5}{|c|}{ Panel A: Number of children } \\
\hline OLS & $\begin{array}{l}-0.025 * * * \\
(0.003)\end{array}$ & $\begin{array}{l}-0.024 * * * \\
(0.003)\end{array}$ & $\begin{array}{l}-0.071 * * * \\
(0.008)\end{array}$ & $\begin{array}{l}-0.071 \text { *** } \\
(0.008)\end{array}$ \\
\hline IV & $\begin{array}{l}-0.489 * * * \\
(0.160)\end{array}$ & $\begin{array}{r}-0.910 \\
(0.564)\end{array}$ & $\begin{array}{l}-0.395 * \\
(0.204)\end{array}$ & $\begin{array}{r}-0.323 \\
(0.203)\end{array}$ \\
\hline \multicolumn{5}{|l|}{ Panel B: Childlessness } \\
\hline OLS & $\begin{array}{l}0.010 * * * \\
(0.001)\end{array}$ & $\begin{array}{l}0.010 * * * \\
(0.001)\end{array}$ & $\begin{array}{l}0.010 * * * \\
(0.002)\end{array}$ & $\begin{array}{l}0.010 \text { *** } \\
(0.002)\end{array}$ \\
\hline IV & $\begin{array}{l}0.144 * * \\
(0.059)\end{array}$ & $\begin{array}{r}0.066 \\
(0.048)\end{array}$ & $\begin{array}{l}0.167 * * * \\
(0.058)\end{array}$ & $\begin{array}{r}0.270 \\
(0.183)\end{array}$ \\
\hline \multicolumn{5}{|l|}{ First stage results } \\
\hline Reform dummy & $\begin{array}{l}0.305 * * * \\
(0.304)\end{array}$ & $\begin{array}{r}0.165 \\
(0.127)\end{array}$ & $\begin{array}{l}0.428 * * * \\
(0.102)\end{array}$ & $\begin{array}{l}0.457 \text { *** } \\
(0.094)\end{array}$ \\
\hline First stage F-statistic & 9.86 & 1.68 & 19.70 & 20.50 \\
\hline \multicolumn{5}{|c|}{ State-specific trends in year of birth } \\
\hline $\begin{array}{l}\text { Linear } \\
\text { Squared } \\
\text { Observations }\end{array}$ & $\checkmark$ & $\begin{array}{l}\sqrt{ } \\
\checkmark\end{array}$ & $\sqrt{ }$ & $\begin{array}{l}\sqrt{ } \\
\sqrt{ }\end{array}$ \\
\hline
\end{tabular}

Notes: Each coefficient represents a separate linear IV regression. Education variable is "length of education" defined as graduation year - year of birth - 6. All regressions include state of residence-fixed effects, year of birth-fixed effects, state-specific trends (linear and quadratic) in year of birth, indicators for marital status and municipality size. Standard errors in parentheses are adjusted for clusters at the state-birth year level. ***, ** and * indicate statistical significance at the $1 \%, 5 \%$ and $10 \%$ level.

Source: German Mikrozensus (MZ) 2008; own calculations. 
Table 9: The effect of education on childlessness and the number of children - alternative selection of analyzed cohorts

\begin{tabular}{|c|c|c|c|c|c|}
\hline \multirow[t]{2}{*}{ Window } & \multicolumn{4}{|c|}{ Symmetric } & \multirow{2}{*}{$\begin{array}{l}\text { Asymmetric } \\
1938-1959\end{array}$} \\
\hline & 4-year & 5-year & 6-year & 7-year & \\
\hline \multicolumn{6}{|c|}{ Panel A: Number of children } \\
\hline \multirow[t]{2}{*}{ IV } & $-0.187 * * *$ & $-0.172 * * *$ & $-0.144 * * *$ & -0.071 & -0.019 \\
\hline & $(0.058)$ & $(0.050)$ & $(0.052)$ & $(0.058)$ & $(0.057)$ \\
\hline \multicolumn{6}{|l|}{ Panel B: Childlessness } \\
\hline \multirow[t]{2}{*}{ IV } & $0.047 * *$ & $0.051 * * *$ & $0.051 * * *$ & $0.050 * * *$ & 0.011 \\
\hline & $(0.022)$ & $(0.018)$ & $(0.016)$ & $(0.019)$ & $(0.018)$ \\
\hline \multicolumn{6}{|l|}{ First stage results } \\
\hline \multirow[t]{2}{*}{ Reform dummy } & $0.708 * * *$ & $0.647 * * *$ & $0.725 * * *$ & $0.672 * * *$ & $0.740 * * *$ \\
\hline & $(0.192)$ & $(0.132)$ & $(0.115)$ & $(0.092)$ & $(0.076)$ \\
\hline First stage F-statistic & 13.65 & 23.89 & 39.81 & 53.53 & 94.61 \\
\hline Observations & 13,897 & 17,428 & 21,053 & 24,620 & 38,310 \\
\hline
\end{tabular}

Notes: Each coefficient represents a separate linear regression. All regressions include state of residence-fixed effects, year of birth-fixed effects, state-specific trends (linear and quadratic) in year of birth, indicators for marital status and municipality size. Standard errors in parentheses are adjusted for clusters at the state-birth year level. $* * *, * *$ and $*$ indicate statistical significance at the $1 \%, 5 \%$ and $10 \%$ level.

Source: German Mikrozensus (MZ) 2008; own calculations. 
Table 10: The effect of education on the age-specific probability of first birth - alternative selection of analyzed cohorts

\begin{tabular}{|c|c|c|c|c|c|}
\hline Age at birth & $15-20$ & $21-25$ & $26-30$ & $31-35$ & $>35$ \\
\hline \multicolumn{6}{|c|}{ Panel A: 5-year window } \\
\hline IV & $\begin{array}{l}-0.029 \\
(0.019)\end{array}$ & $\begin{array}{l}-0.026 \\
(0.036)\end{array}$ & $\begin{array}{r}0.052 \\
(0.033)\end{array}$ & $\begin{array}{r}-0.078 \\
(0.048)\end{array}$ & $\begin{array}{r}0.040 \\
(0.032)\end{array}$ \\
\hline $\begin{array}{l}\text { First stage results } \\
\text { First stage F-Statistic }\end{array}$ & 15.01 & 14.58 & 34.57 & 33.77 & 11.84 \\
\hline Observations & 1,911 & 1,599 & 1,044 & 606 & 444 \\
\hline \multicolumn{6}{|c|}{ Panel B: 9-year window } \\
\hline IV & $\begin{array}{l}-0.055 * * \\
(0.026)\end{array}$ & $\begin{array}{l}-0.041 \\
(0.039)\end{array}$ & $\begin{array}{r}0.012 \\
(0.040)\end{array}$ & $\begin{array}{r}-0.018 \\
(0.062)\end{array}$ & $\begin{array}{r}-0.019 \\
(0.052)\end{array}$ \\
\hline $\begin{array}{l}\text { First stage results } \\
\text { First stage F-Statistic }\end{array}$ & 20.35 & 12.21 & 20.18 & 12.07 & 5.96 \\
\hline Observations & 3,403 & 2,872 & 1,878 & 1,090 & 785 \\
\hline
\end{tabular}

Note: Probability of childbearing at a given age. Each coefficient represents a separate linear regression. All regressions include state of residence-fixed effects, year of birth-fixed effects, squared state-specific trends in year of birth, indicators for marital status, municipality size, and mothers' age at birth. Standard errors in parentheses are adjusted for clusters at the state-birth year level. $* * *, * *$ and $*$ indicate statistical significance at the $1 \%, 5 \%$ and $10 \%$ level.

Source: SOEP 1984-2010; own calculations. 


\section{A Appendix}

Table A.1: Effect of education on fertility - SOEP results

\begin{tabular}{|c|c|c|c|c|}
\hline & \multicolumn{2}{|c|}{ 7-year window } & \multicolumn{2}{|c|}{ 5-year window } \\
\hline \multicolumn{5}{|c|}{ Panel A: number of children } \\
\hline OLS & $\begin{array}{l}-0.015 * \\
(0.008)\end{array}$ & $\begin{array}{l}-0.015 * \\
(0.008)\end{array}$ & $\begin{array}{l}-0.018 * * \\
(0.009)\end{array}$ & $\begin{array}{l}-0.018 * * \\
(0.009)\end{array}$ \\
\hline IV & $\begin{array}{r}-0.074 \\
(0.099)\end{array}$ & $\begin{array}{l}-0.172 * \\
(0.088)\end{array}$ & $\begin{array}{r}-0.112 \\
(0.077)\end{array}$ & $\begin{array}{r}-0.064 \\
(0.095)\end{array}$ \\
\hline \multicolumn{5}{|l|}{ Panel B: childlessness } \\
\hline OLS & $\begin{array}{l}0.007 * * \\
(0.003)\end{array}$ & $\begin{array}{l}0.007 * * \\
(0.003)\end{array}$ & $\begin{array}{l}0.009 * * * \\
(0.003)\end{array}$ & $\begin{array}{l}0.009 * * * \\
(0.003)\end{array}$ \\
\hline IV & $\begin{array}{r}0.012 \\
(0.022)\end{array}$ & $\begin{array}{l}0.053 * * * \\
(0.019)\end{array}$ & $\begin{array}{l}0.032 * * \\
(0.015)\end{array}$ & $\begin{array}{r}0.014 \\
(0.016)\end{array}$ \\
\hline \multicolumn{5}{|l|}{ First stage results } \\
\hline Reform dummy & $\begin{array}{l}1.123 * * * \\
(0.300)\end{array}$ & $\begin{array}{l}1.638 * * * \\
(0.399) \\
14053\end{array}$ & $\begin{array}{l}1.534 * * * \\
(0.401) \\
14635\end{array}$ & $\begin{array}{l}1.839 * * * \\
(0.475)\end{array}$ \\
\hline First stage F-statistic & 14.053 & 14.053 & 14.635 & 15.013 \\
\hline \multicolumn{5}{|c|}{ State-specific trends in year of birth } \\
\hline $\begin{array}{l}\text { Linear } \\
\text { Squared } \\
\text { Observations }\end{array}$ & $\checkmark$ & $\begin{array}{l}\sqrt{ } \\
\sqrt{ }\end{array}$ & $\sqrt{ }$ & $\begin{array}{l}\sqrt{ } \\
\sqrt{ }\end{array}$ \\
\hline
\end{tabular}

Notes: Each coefficient represents a separate linear regression. All regressions include state of residence-fixed effects, year of birth-fixed effects, indicators for marital status, municipality size, and mothers' age at birth. Standard errors in parentheses are adjusted for clusters at the state-birth year level. ***,** and * indicate statistical significance at the $1 \%, 5 \%$ and $10 \%$ level.

Source: SOEP 1984-2010; own calculations. 